\title{
Synthesis, Characterization and Physicochemical Analysis of Some Mannofuranoside Derivatives with Potent Antimicrobial Activity
}

\author{
FIROJ HASSAN ${ }^{1}$, MALIK NASIBULLAH ${ }^{1}$, NASEEM AHMAD ${ }^{1}$, AZHAR KAMAL ${ }^{2}$, SYED \\ MOHAMMAD DANISH RIZVI ${ }^{3}$, MOHD SAJID KHAN ${ }^{2}$ and ABDUL RAHMAN KHAN ${ }^{\text {* }}$ *
}

\author{
${ }^{1}$ Department of Chemistry, Kursi Road, Integral University, Lucknow-226026, India. \\ ${ }^{2}$ Department of Biosciences, Kursi Road, Integral University, Lucknow-226026, India. \\ ${ }^{3}$ Department of Pharmacology \& Toxicology, College of Pharmacy \\ University of Hail, PO Box no. 2440, Saudi Arabia. \\ *Corresponding author E-mail: firojhassan42@gmail.com, arahman@iul.ac.in
}

http://dx.doi.org/10.13005/ojc/330606

(Received: August 25, 2017; Accepted: September 20, 2017)

\begin{abstract}
We have synthesized protected mannofuranose as a glycosyl donor and some heterocyclic moieties as glycosyl acceptor. Coupling of glycosyl donor and acceptor by glycosylation, results in the formation of mannofuranoside derivatives. Antimicrobial potential of synthesized compounds were tested against five different human pathogenic bacteria and two fungi by using microdilution method. Interestingly, all synthesized mannofuranoside derivatives gave antimicrobial activity. Cumulatively, inhibitory concentration $\left(\mathrm{IC}_{50}\right)$ against bacteria were found to be in the range of $84.28-309.43 \mu \mathrm{g} / \mathrm{ml}$, while, $I C_{50}$ against fungus were in the range of $0.59-3.82 \mathrm{mg} / \mathrm{ml}$. Ampicillin and Fluconazole were used as positive control. Further, physicochemical parameters of synthesized mannofuranoside derivatives were analyzed using in-silico approach. Fortunately, none of our synthesized mannofuranoside derivatives gave violation of Lipinski's Rule of Five. Thus, we can safely state that these synthesized mannofuranoside derivatives could be considered as potential anti-microbial drug candidates.
\end{abstract}

Keywords: Glycosylation, Mannofuranoside, Antibacterial, Antifungal, Physicochemical parameter.

\section{INTRODUCTION}

Microbial food contaminations have been the cause of severe public health concern over the last few decades' ${ }^{1}$ hence antibacterial and antifungal agents are necessary for food preservation. Many researchers have focused their research on finding high potential antibacterial and antifungal agents ${ }^{2}$.
The potential of sugars as starting compounds for highly efficient syntheses of carbohydrate conjugates are now well recognized with regard to antibacterial, antiviral, antineoplastic, antiprotozoal and antifungal activity ${ }^{3-9}$. Heterocyclic chemistry has wide array of biologically active compounds isolated from natural sources or synthesized in the laboratory, such as coumarins ${ }^{10-12}$, quinolines ${ }^{13,14}$, 
triazoles ${ }^{15}$ and phenolics ${ }^{16,17}$ etc. They are also if present as a part of giant molecule, imparting significant activity to these molecules. From the previous studies, it is realized that heterocyclic and aromatic rings are coupled with carbohydrate to enhance the biological activity ${ }^{18}$ like some acyl-substituted D-glucofuranose were discovered as more biologically active than D-glucofuranose. ${ }^{19}$ furthermore, when biologically active molecule is connected to another nuclei may possess excellentbiological activity. ${ }^{20}$

Several glycoconjugates such as glycolipids, glycoproteins or glycopeptides \& glycosylated natural products are frequently being used as antimicrobial drugs and also emerging as anti-cancer drug candidates ${ }^{21-28}$. Encouraged by these results, we have synthesized some glycosides for antibacterial and antifungal evaluation. During the synthesis of glycosides, protection of a particular functional group of monosaccharides is not only necessary for the modification of the remaining functional groups but also useful during the synthesis of novel derivatives of great importance ${ }^{29,30}$. Glycosylation of alcohol-acceptor precursor as heterocycles, with O-(2,3,5,6-di-O- $\alpha$-Dmannofuranosyl) trichloroacetimidate ${ }^{36}$, as donor precursor in the presence of catalyst trimethylsilyl trifluoromethanesulfonate (TMSOTf) to give glycosidic products ${ }^{31}$, further antimicrobial activity of synthesized compounds were evaluated using various strains of bacteria\& fungi to determine Inhibitory Concentration $\left(\mathrm{IC}_{50}\right)^{32-35}$.

\section{MATERIALS AND METHODS}

All the synthesized compounds were routinely checked for their purity on silica gel 60 (E. Merck) TLC plates and their spots were visualized by charring the plates with $5 \% \mathrm{H}_{2} \mathrm{SO}_{4}$ in $\mathrm{MeOH}$. Column chromatography on Merck silica gel (100-200 mesh) was used for the purification of synthesized compounds. Combined organic extract were dehydrated using anhydrous $\mathrm{Na}_{2} \mathrm{SO}_{4}$ and dried solutions were evaporated under vacuum. Solvents used in column chromatography were purchased from E. Merck, sd fine chemicals and Qualigens. Reagents used in the synthesis were purchased from, Avara syntheses, Sigma Aldrich and Himedia.

\section{Apparatus}

Electronics India, model-934 used for the determination of Melting points. ES mass spectra were recorded in Merck M-8000 LCMS system or Micromass Quadro LCMS system and HR/El mass were done on JEOL-600H at $70 \mathrm{eV}$. Proton NMR and ${ }^{13} \mathrm{C}-\mathrm{NMR}$ spectra were recorded on Bruker Avance DPX-300 MHz or Avance DPX-200 MHz FT Bruker spectrometers, using deuteriated solvents and Tetramethyl Silane as an internal standard. The chemical shift values from downfield to upfield in both proton NMR and ${ }^{13} \mathrm{C}$-NMR spectra. For synthesized compounds, proton NMR data is recorded in the order; chemical shifts values in ppm $(\delta)$, multiplicities are indicated as bs (broadened singlet), s (singlet), d (doublet), dd (double doublet), $\mathrm{t}$ (triplet), q (quartet) and $\mathrm{m}$ (multiplet). Coupling constant 'J' reported in Hz. Perkin-Elmer's Spectrum RXIFT-IR spectrophotometer was used for recording $\mathrm{IR}$ spectra using $\mathrm{KBr}$ disc. Elemental analysis was carried out on Carlo-Erba-1108 instrument.

\section{RESULTS AND DISCUSSION}

The glycosyl donor was synthesized from D-mannose, led to the formation of 2,3,5,6-di-Oisopropylidene- $\alpha$-D-mannofuranose (C1). The later was treated with trichloroacetonitrile to gave 2,3,5,6di-O-isopropylidene-1-O-trichloroacetamidyl- $\alpha$-Dmannofuranose (C2) in Scheme- ${ }^{36}$.

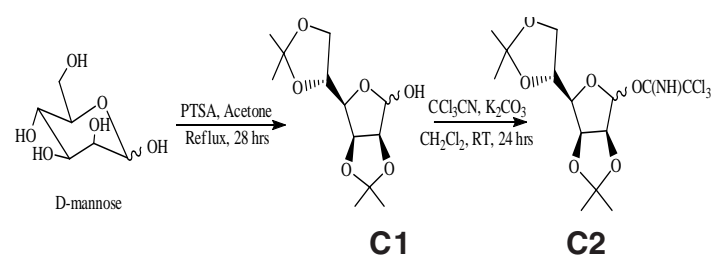

Scheme 1. Synthesis of mannofuranosyl donor ${ }^{36}$

The structure of the $\mathrm{C} 1$ was in accordance with its spectroscopic data such as proton NMR, isopropylidene group $\left(>\mathrm{C}\left(\mathrm{CH}_{3}\right)_{2}\right)$ at $\delta$ 1.46-1.33 ppm. ${ }^{13} \mathrm{C}$ NMR spectrum displayed signal of methyl carbons of isopropylidene group $\left(>\mathrm{C}\left(\mathrm{CH}_{3}\right)_{2}\right)$ at $\delta$ 25.8-27.0 ppm. The mass spectra gave a peak at $261(\mathrm{M}+1)$. FT-IR for $-\mathrm{OH}$ at $3431 \mathrm{~cm}^{-1}$ with $87 \%$ yield. The synthesized glycosyl donor (C2) was established by proton NMRsignals at $\delta 8.59 \mathrm{ppm}$ for $-\mathrm{NH}$ group ${ }^{13} \mathrm{C}$ NMR spectrum displayed signal of methyl carbons of isopropylidene group $\left(>\mathrm{C}\left(\mathrm{CH}_{3}\right)_{2}\right) \delta 27.1-24.9 \mathrm{ppm}$, at $\delta 160.8 \mathrm{ppm}$ for acetamidyl carbon. Mass spectrum gave a peak at 
$403(\mathrm{M}+1)$, FT-IR for -NH group was $3794 \mathrm{~cm}^{-1}$ with $66 \%$ yield.

The aglycon 7-(2-hydroxyethoxy)-4methyl coumarin (C3) was synthesized by the reaction of 7-hydroxy-4-methyl coumarin with 2-bromoethanol and potassium carbonate in the presence of ethanol in Scheme-2. ${ }^{37}$<smiles>Cc1cc(=O)oc2cc(OCCO)ccc12</smiles>
C3

Scheme 2. Synthesis of 7-(2-hydroxyethoxy)-4methyl coumarin

The structure of C3 was established by proton NMR, ${ }^{13} \mathrm{C}$ NMR, Mass and FT-IR. Proton NMRspectra gave a triplet at $\delta 3.69 \mathrm{ppm},\left(-\mathrm{CH}_{2} \mathrm{OH}\right)$, and $\delta 4.33 \mathrm{ppm}\left(-\mathrm{CH}_{2} \mathrm{OAr}\right) \cdot{ }^{13} \mathrm{C}$ NMR spectrum displayed a signal at $\delta 61.3 \mathrm{ppm}\left(-\mathrm{CH}_{2} \mathrm{OH}\right)$, at $\delta$ $69.9 \mathrm{ppm}\left(-\mathrm{CH}_{2} \mathrm{OAr}\right)$ and at $\delta 161.9 \mathrm{ppm}$ for carbonyl carbon, Mass spectrum gave a peak at $221(\mathrm{M}+1)$, FT-IR gave frequency $3452 \mathrm{~cm}^{-1}(-\mathrm{OH}), 1720 \mathrm{~cm}^{-1}$ $(>\mathrm{C}=\mathrm{O}$ ) for compound $\mathrm{C} 3$ with $58 \%$ yield.

Glycosylation of $\mathrm{C} 3$ as an alcoholacceptor, with 2,3,5,6-di-O-isopropylidene-1-Otrichloroacetamidyl- $\alpha$-D-mannofuranose, C2 as donor in the presence of trimethylsilyl trifluoromethanesulfonate (TMSOTf) and $4 \mathrm{~A}^{\circ}$ molecular sieve in anhydrous dichloromethane gave 7-O-ethoxy- $\alpha$-(2,3,5,6-di-O-isopropylidenemannofuranosyl)-4-methyl-coumarin (C4) (Scheme-3) as colorless crystalline solid. Chemical structure of the compound C4 was confirme of isopropylidene proton $\left(>\mathrm{C}\left(\mathrm{CH}_{3}\right)_{2}\right)$ singlet at $\delta 1.49$ $1.32 \mathrm{ppm}$, singlet at $\delta 1.97 \mathrm{ppm}\left(-\mathrm{CH}_{3}\right)$, triplet at $\delta$ 3.69 ppm $\left(-\mathrm{C}_{2} \mathrm{CH}_{2} \mathrm{OAr}\right)$ and also a triplet at $\delta 4.33$ ppm $\left(-\mathrm{CH}_{2} \mathrm{CH}_{2} \mathrm{OAr}\right) .{ }^{13} \mathrm{C}$ NMR spectrum displayed signal of methyl carbons of isopropylidene group $\left(>\mathrm{C}\left(\mathrm{CH}_{3}\right)_{2}\right)$ at $\delta 26.8-26.0 \mathrm{ppm}$, at $\delta 18.9 \mathrm{ppm}\left(-\mathrm{CH}_{3}\right)$, at $\delta 61.3 \mathrm{ppm}\left(-\mathrm{CH}_{2} \mathrm{CH}_{2} \mathrm{OAr}\right)$, at $\delta 69.8 \mathrm{ppm}$ $\left(-\mathrm{CH}_{2} \mathrm{CH}_{2} \mathrm{OAr}\right)$ and at $\delta 164.1 \mathrm{ppm}$ for carbonyl carbon, Mass spectrum gave a peak at $463(\mathrm{M}+1)$, FT-IR gave frequency at $1720 \mathrm{~cm}^{-1}(>\mathrm{C}=\mathrm{O}), 3280$, $2988 \mathrm{~cm}^{-1}\left(-\mathrm{CH}_{3}\right.$ and $-\mathrm{CH}_{2}$ stretching), while frequency for $-\mathrm{OH}$ was absent. The proton NMRsignals of $-\mathrm{OH}$ and $-\mathrm{NH}$ was absent in $\mathrm{C} 4$, formed with $59 \%$ yield.

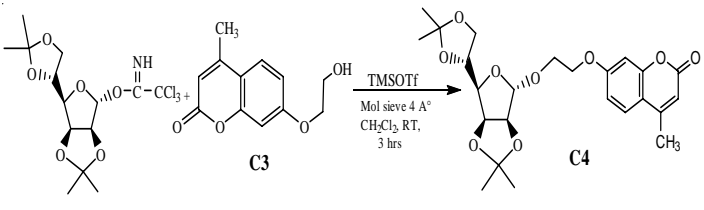

Scheme 3. Catalysed glycosidation of coumarin derivatives with glycosyl donor

Synthesized glycosyl donor of D-mannose C2 was reacted with Glycosyl acceptor vanillin in the presence of trimethylsilyl trifluoromethanesulfonate (TMSOTf), $4 \mathrm{~A}^{\circ}$ molecular sieve in anhydrous dichloromethane to formed 3-Omethoxy-4'-O- $\alpha$ - $(2,3,5,6$-di-O-isopropylidenemannofuranosyl) benzoic acid (C5) Chemical structure of the compound C5 was confirmed by proton NMR, and FT-IR.Proton NMRspectra gave signals of isopropylidene proton $\left(>\mathrm{C}\left(\mathrm{CH}_{3}\right)_{2}\right)$ singlet at $\delta$ 1.56-1.32 ppm, singlet at $\delta 3.92 \mathrm{ppm}\left(-\mathrm{OCH}_{3}\right)$ and also a singlet at $\delta 11.74 \mathrm{ppm}(-\mathrm{COO} \underline{\mathrm{H}}) .{ }^{13} \mathrm{C}$ NMR spectrum displayed signal of methyl carbons of isopropylidene group $\left(>\mathrm{C}\left(\mathrm{CH}_{3}\right)_{2}\right)$ at $\delta$ 26.2-23.8 ppm, at $\delta 56.2 \mathrm{ppm}\left(-\mathrm{OCH}_{3}\right)$ and at $\delta 169.5 \mathrm{ppm}$ for carbonyl carbon, Mass spectrum gave a peak at $411(\mathrm{M}+1)$, FT-IR gave frequency at $1690 \mathrm{~cm}^{-1}$ $(>\mathrm{C}=\mathrm{O}), 3298,2925$ and $2870 \mathrm{~cm}^{-1}\left(-\mathrm{CH}_{3}\right.$ and $-\mathrm{CH}_{2}$ stretching), while frequency for $-\mathrm{OH}$ was absent. The proton NMRsignals of $-\mathrm{OH}$ and $-\mathrm{NH}$ was absent in C5. It was formed with $45 \%$ yield.

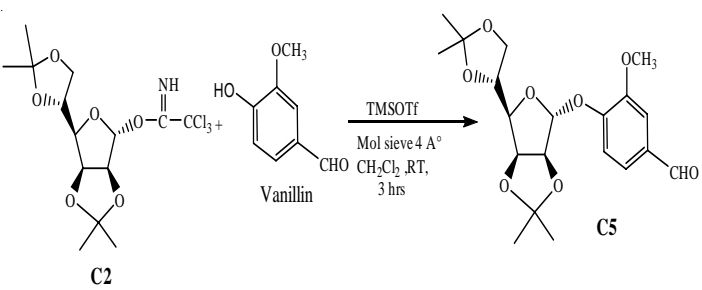

Scheme 4. Synthesis of mannosylated phenolics

Synthesized glycosyl donor C2 was coupled with 8-Hydroxy quinoline, 1-Hydroxy benzotriazole and 2-(Hydroxymethyl) furan in the presence of catalytic amount of trimethylsilyl trifluoromethanesulfonate (TMSOTf), 4A ${ }^{\circ}$ molecular sieve in anhydrous dichloromethane at room temperature to gave $8-0-\alpha-(2,3,5,6-d i-O$ isopropylidene-mannofuranosyl)-quinoline (C6), 1-O- $\alpha-(2,3,5,6-d i-O-i s o p r o p y l i d e n e ~ m a n n o f u r a n o s y l)-$ $1 \mathrm{H}$-benzo-1,2,3-triazole (C7) and2-O-methyl- $\alpha$ (2,3,5,6-di-O-isopropylidene-mannofuranosyl) furan (C8) with 56, 67, 69\% yield respectively. Structure of these compounds was established by proton NMR, ${ }^{13} \mathrm{C}$ NMR, Mass and FT-IR. 
Proton NMRspectra of $\mathrm{C} 6$ gave signals of isopropylidene proton $\left(>\mathrm{C}\left(\mathrm{CH}_{3}\right)_{2}\right)$ singlet at $\delta$ 1.36$1.25 \mathrm{ppm}$, doublet at $\delta 8.73 \mathrm{ppm}(\mathrm{H}-1)$, triplet at $\delta$ $7.52 \mathrm{ppm}(\mathrm{H}-2)$, doublet at $\delta 7.58 \mathrm{ppm}(\mathrm{H}-3)$ and multiplet at $\delta$ 7.41-7.16 ppm. ${ }^{13} \mathrm{C}$ NMR spectrum displayed signal of methyl carbons of isopropylidene group $\left(>\mathrm{C}\left(\mathrm{CH}_{3}\right)_{2}\right)$ at $\delta 27.0-24.7 \mathrm{ppm}$, carbon of aromatic ring was observed at $\delta 163.9$, 152.3, 148.0, 138.4, 136.3, 128.7, 127.9, 122.0, 118.1 ppm, Mass spectrum gave a peak at $388(\mathrm{M}+1)$, FTIR gave frequency at 2988 and $2881 \mathrm{~cm}^{-1}\left(-\mathrm{CH}_{3}\right.$ and $-\mathrm{CH}_{2}$ stretching), while frequency for $-\mathrm{OH}$ was absent.

Proton NM Rspectra of $\mathrm{C} 7$ gave signals of isopropylidene proton $\left(>\mathrm{C}\left(\mathrm{CH}_{3}\right)_{2}\right)$ at $\delta 1.47-1.31 \mathrm{ppm}$ and multiplet at $\delta 7.69-7.38 \mathrm{ppm}(\mathrm{Ar}-\mathrm{H}) .{ }^{13} \mathrm{C}$ NMR spectrum displayed signal of methyl carbons of isopropylidene group $\left(>\mathrm{C}\left(\mathrm{CH}_{3}\right)_{2}\right)$ at $\delta 26.0-24.7 \mathrm{ppm}$, carbons of aromatic ring was observed at $\delta 144.8$, $144.7,135.1,130.8,129.8,129.6,128.8$, ppm, Mass spectrum gave a peak at $378(\mathrm{M}+1)$, FT-IR gave frequency at 3039 and $2917 \mathrm{~cm}^{-1}\left(-\mathrm{CH}_{3}\right.$ and $-\mathrm{CH}_{2}$ stretching), while frequency for $-\mathrm{OH}$ was absent.

Proton NMR spectra of $\mathrm{C} 8$ gave signals of isopropylidene proton $\left(>\mathrm{C}\left(\mathrm{CH}_{3}\right)_{2}\right)$ singlet at $\delta 1.42$ $1.329 \mathrm{ppm}$, singlet at $\delta 3.92 \mathrm{ppm}(\mathrm{H}-1)$, doublet at $\delta$ $6.24 \mathrm{ppm}(\mathrm{H}-2)$, triplet at $\delta 6.27 \mathrm{ppm}(\mathrm{H}-3)$, doublet at $\delta 6.98 \mathrm{ppm}(\mathrm{H}-4) \cdot{ }^{13} \mathrm{C}$ NMR spectrum displayed signal of methyl carbons of isopropylidene group $\left(>\mathrm{C}\left(\mathrm{CH}_{3}\right)_{2}\right)$ at $\delta 26.0-24.7 \mathrm{ppm}$, carbons of furan ring was observed at $\delta 152.8,143.8,113.7,112.7 \mathrm{ppm}$, Mass spectrum gave a peak at $341(\mathrm{M}+1)$, FT-IR gave frequency at 3282 and $2974 \mathrm{~cm}^{-1}\left(-\mathrm{CH}_{3}\right.$ and $-\mathrm{CH}_{2}$ stretching), while frequency for $-\mathrm{OH}$ was absent. The proton NMR signals of $-\mathrm{OH}$ and $-\mathrm{NH}$ was absent in $\mathrm{C} 6, \mathrm{C} 7$ and $\mathrm{C} 8$.

\section{Antibacterial activity \\ Determination of inhibitory concentration $\left(\mathrm{IC}_{50}\right)$ :}

Thedisk diffusion method ${ }^{38}$ was used for the preliminary antibacterial evaluation of compounds $\mathrm{C} 1, \mathrm{C} 2, \mathrm{C} 4-\mathrm{C} 8$. The inhibitory concentrations $\left(\mathrm{IC}_{50}\right)$ of mannofuranoside derivatives showing inhibition in the preliminary tests, were determined by the microtitre plate technique using micro dilution method (Table-1) ${ }^{39}$ Briefly, Staphylococcus aureus (ATCC 6538), Bacillus pumilis (MTCC 160), Bacillus subtilis (MTCC 441), Bacillus cerius (MTCC1305), Escherichia coli (ATCC 25923), obtained from NCIM
NCL Pune, India were grown to mid-logarithmic phase and harvested by centrifugation, washed with $10 \mathrm{mM}$ sodium phosphate buffer (SPB) at pH 7.4, and diluted to $2 \times 10^{5}$ colony forming units (CFU)/ $\mathrm{ml}$ in SPB containing $0.03 \%$ Nutrient broth (NB). Mannofuranoside derivatives were serially diluted in $250 \mu \mathrm{L}$ of nutrient broth (NB) medium in 96-well microtitre plates to achieve the desired concentrations $(25-400 \mu \mathrm{g} / \mathrm{ml})$ with bacterial inoculum $\left(5 \times 10^{4} \mathrm{CFU}\right.$ per well).After incubation at $37^{\circ} \mathrm{C}$ overnight, the $I \mathrm{IC}_{50}$ was taken of the synthesized compound that provides a $50 \%$ reduction in growth of bacterial strains compared to the growth in the control well.

\section{Antifungal activity \\ Determination of inhibitory concentration $\left(\mathrm{IC}_{50}\right)$ :}

The utilization of microplate bioassays, or broth microdilution tests, to measure the biological action of synthetic compounds against fungal pathogens has expanded in recent years. This method has been recognized as the most encouraging invitro bioassay for evaluating antifungal activity ${ }^{40,41}$. The antifungal strains $A$. flavus (MTCC 277) and T. viridens (MTCC 167) for the test were obtained from NCIM, NCL Pune, India. Mannofuranoside derivatives were serially diluted in $250 \mu \mathrm{l}$ of SD medium in 96-well microtitre plates to achieve the desired concentrations $(0.5-5 \mathrm{mg} /$ $\mathrm{ml}$ ) with fungal inoculum $\left(5 \times 10^{2} \mathrm{CFU}\right.$ per well). The invitro antifungal activities of the test compounds under investigation were also done by Poisons Food technique ${ }^{42}$ and the technique was used with some modification by ${ }^{43}$ using $0.5-5 \mathrm{mg}$ of compounds per $\mathrm{ml}$ of Sabouraud Dextrose (SD) medium. The diameter of radial growth of the test fungi was measured after 2 to 3 days of incubation at $27 \pm 1^{\circ} \mathrm{C}$ and expressed as percent mycelia growth inhibition following the formula given below:
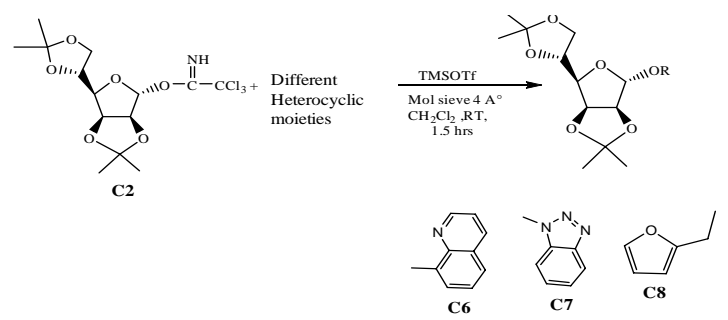

Scheme 5. Catalysed glycosidation of different heterocycles with glycosyl donor 


$$
\mathrm{I}=\mathrm{C}-\mathrm{T} / \mathrm{CX} 100
$$

Where, I = Percentage of inhibition.

$\mathrm{C}=$ Optical density of the fungal colony at $595 \mathrm{~nm}$ in control (DMSO)

$\mathrm{T}=$ Optical density of the fungal colony in treatment. Calculation of Physicochemical Properties

To check the physicochemical properties of synthesized mannofuranoside derivatives, Molinspiration property count instrument(http:// www.molinspiration.com/cgi-bin/properties) was utilized. Different parametersas topological polar surface area (TPSA), molecular weight, miLogP, the number of hydrogen bond donors, the number of hydrogen bond acceptors, number of rotatable bonds, and violations of Lipinski's rule of five ${ }^{44}$ were estimated using Molinspiration tool [Table-2]. Moreover, Absorption \% was ascertained by the strategy for Zhao et al. (2002) utilizing the recipe

$\%$ of Absorption $=109[0.345 \times$ TPSA $]$

\section{Physicochemical properties prediction}

Earlier, lead drug compounds fails at different clinical trials stages as a result of in appropriate pharmacokinetic profiling. But, now- adays to cut down these failures, physicochemical profiling of new drug candidates has become an important part of drug discovery. These analyses involve assessment of various molecular descriptors that would help in prediction of druglikeliness. There are various in- silico tools available to calculate the molecular properties of a compound to assess its pharmacokinetic profile. In fact, these in-silico tools have helped a lot to overcome the issues related to the failure of clinical trials ${ }^{45,46}$.

Molinspiration is a tool which was used in the present study to screen the pharmacokinetic property of mannofuranoside derivatives i.e., C1, C2, C4-C8. According to the Lipinski's Rule of Five (Lipinski et al., 2001) studied mannofuranoside derivatives posses' drug like property [Table-2]. Lipinski's Rule of Five is based on the observation that the majority of oral drugs have a molecular weight $\geq 5000$, Log $P$ value $\geq 5$, hydrogen bond donor $\geq 5$, hydrogen bond acceptor $\geq 10$ and rotatable bonds $\geq 10$. Any compound which violates more than one of these rules might have problem. Interestingly, none of our synthesized mannofuranoside derivatives gave violation of Lipinski's Rule of Five. Thus, we can safely state that these compounds could be considered as potential drug candidates.

The growth inhibition of different strains of bacteria (S. aureus (ATCC 6538), B. pumilis (MTCC 160), B. subtilis (MTCC 441), B. cerius

Table. 1: Antibacterial $\left(\mathrm{IC}_{50} \mu \mathrm{g} / \mathrm{ml}\right)$ and Antifungal activity $\left({ }^{*} \mathrm{I} \mathrm{C}_{50} \mathrm{mg} / \mathrm{ml}\right)$ of compounds C1, C2, C4-C8

\begin{tabular}{|c|c|c|c|c|c|c|c|}
\hline Compounds & S. aureus & B. pumilis & B. Subtilis & B. cerius & E.coli & A. flavus & T. viridens \\
\hline C1 & NA & NA & NA & NA & NA & $1.84( \pm 0.04)$ & $1.86( \pm 0.02)$ \\
\hline $\mathrm{C} 2$ & $\begin{array}{l}267.67 \\
( \pm 0.17)\end{array}$ & NA & NA & NA & NA & $1.09( \pm 0.01)$ & $2.30( \pm 0.05)$ \\
\hline $\mathrm{C} 4$ & NA & NA & $\begin{array}{l}157.61 \\
( \pm 0.32)\end{array}$ & NA & NA & $1.18( \pm 0.05)$ & $1.66( \pm 0.03)$ \\
\hline C5 & $\begin{array}{l}234.62 \\
( \pm 0.16)\end{array}$ & $\begin{array}{l}221.65 \\
( \pm 0.25)\end{array}$ & NA & $\begin{array}{l}309.43 \\
( \pm 0.19)\end{array}$ & NA & $2.21( \pm 0.03)$ & $1.08( \pm 0.01)$ \\
\hline C6 & $\begin{array}{c}84.28 \\
( \pm 0.11)\end{array}$ & $\begin{array}{l}101.12 \\
( \pm 0.13)\end{array}$ & $\begin{array}{l}102.68 \\
( \pm 0.16)\end{array}$ & $\begin{array}{l}154.78 \\
( \pm 0.21)\end{array}$ & $\begin{array}{l}178.96 \\
( \pm 0.31)\end{array}$ & $0.75( \pm 0.02)$ & $0.59( \pm 0.01)$ \\
\hline $\mathrm{C7}$ & NA & NA & NA & $\begin{array}{l}156.67 \\
( \pm 0.34)\end{array}$ & NA & $1.23( \pm 0.05)$ & $2.98( \pm 0.04)$ \\
\hline $\mathrm{C} 8$ & $\begin{array}{l}294.15 \\
( \pm 0.31)\end{array}$ & NA & NA & NA & NA & $2.91( \pm 0.02)$ & $3.82( \pm 0.03)$ \\
\hline Ampicillin & $\begin{array}{c}4.14 \\
( \pm 0.7)\end{array}$ & $\begin{array}{c}14.15 \\
( \pm 0.06)\end{array}$ & $\begin{array}{c}11.11 \\
( \pm 0.09)\end{array}$ & $\begin{array}{c}8.51 \\
( \pm 0.42)\end{array}$ & $\begin{array}{c}28.03 \\
( \pm 0.10)\end{array}$ & - & - \\
\hline Fluconazole & - & - & - & - & - & $0.10( \pm 0.01)$ & $0.08( \pm 0.01)$ \\
\hline
\end{tabular}

NA, not active, $( \pm)$ shows SD 
Table. 2: Physicochemical Parameters of Compounds C1, C2, C4-C8 and standard drugs

\begin{tabular}{|c|c|c|c|c|c|c|c|c|}
\hline \multirow[t]{2}{*}{ Compounds } & \multicolumn{8}{|c|}{ Physiochemical parameters } \\
\hline & $\% \mathrm{Abs}^{\mathrm{a}}$ & TPSA $^{\mathrm{b}}$ & $\mathrm{MW}^{\mathrm{c}}$ & miLog $\mathrm{P}^{d}$ & $\mathrm{HBD}^{\mathrm{e}}$ & $\mathrm{HBA}^{\mathrm{f}}$ & $\mathrm{RB}^{\mathrm{g}}$ & Lip. vio \\
\hline Rule & - & - & $<500$ & d"5 & $<5$ & $<10$ & d"10 & d"1 \\
\hline C1 & 86.09 & 66.40 & 260.29 & 0.70 & 1 & 6 & 1 & 0 \\
\hline $\mathrm{C} 2$ & 81.65 & 79.26 & 404.67 & 2.85 & 1 & 7 & 4 & 0 \\
\hline C4 & 76.27 & 94.85 & 462.50 & 3.30 & 0 & 9 & 6 & 0 \\
\hline C5 & 73.83 & 101.94 & 410.42 & 2.52 & 1 & 9 & 5 & 0 \\
\hline C6 & 85.43 & 68.30 & 387.43 & 2.97 & 0 & 7 & 3 & 0 \\
\hline $\mathrm{C7}$ & 79.28 & 86.12 & 377.40 & 2.34 & 0 & 9 & 3 & 0 \\
\hline $\mathrm{C} 8$ & 85.35 & 68.54 & 340.37 & 2.17 & 0 & 7 & 4 & 0 \\
\hline Ampicillin & 70.10 & 112.73 & 349.41 & -0.87 & 4 & 7 & 4 & 0 \\
\hline Fluconazole & 80.82 & 81.66 & 306.88 & -0.12 & 1 & 7 & 5 & 0 \\
\hline
\end{tabular}

$\% \mathrm{Abs}^{\mathrm{a}}=\%$ of Absorption= 109 [0.345 $\times$ Topologicl Polar Surface Area]

TPSA $^{b}=$ Topological Polar Surface Area $(\AA)^{2}$

$\mathrm{MW}^{\mathrm{c}}=$ Molecular Weight

miLog $\mathrm{P}^{\mathrm{d}}=$ Logarithm of compound partition coefficient between $n$-octanol and water

$\mathrm{HBD}^{\mathrm{e}}=$ Hydrogen Bond Donors

$\mathrm{HBA}^{\dagger}=$ Hydrogen Bond Acceptors

$\mathrm{RB}^{\mathrm{g}}=$ Rotatable bond

Lip. vio ${ }^{i}=$ Lipinski's Violation

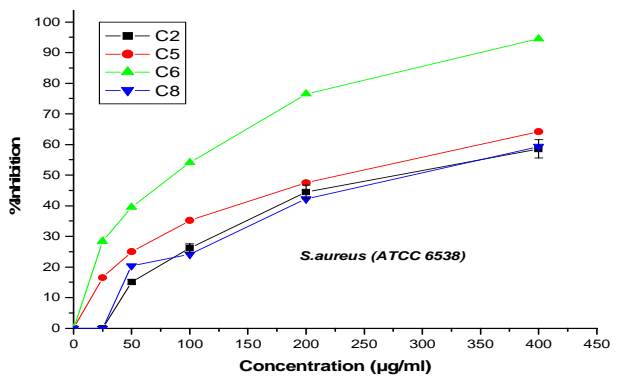

Fig.1. Growth Inhibition of S. aureus at Different Concentration of Synthesized Mannofuranoside Derivatives (C2, C5, C6 \& C8) was Recorded After 18 hours

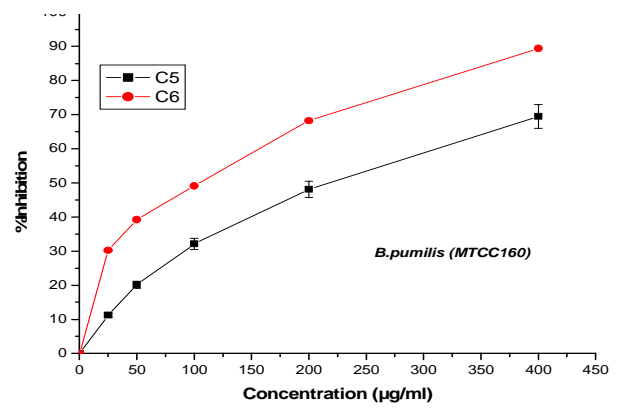

Fig.2. Growth Inhibition of B. pumilis at Different Concentration of Synthesized Mannofuranoside Derivatives (C5 \& C6) was Recorded After 20 hours

(MTCC1305), E. coli (ATCC 25923) and fungi $A$. flavus (MTCC 277), T. viridens (MTCC 167) obtained from NCIM, National chemical laboratories, Pune) at different concentration were presented in Fig. 1-7.

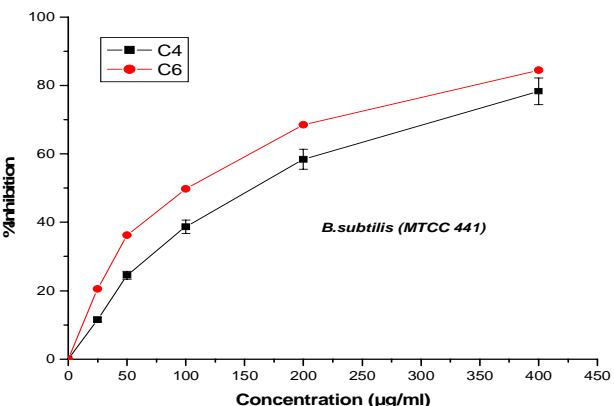

Fig.3. Growth Inhibition of $B$. subtilis at Different Concentration of Synthesized Mannofuranoside Derivatives (C4, \& C6) was Recorded After 20 hours

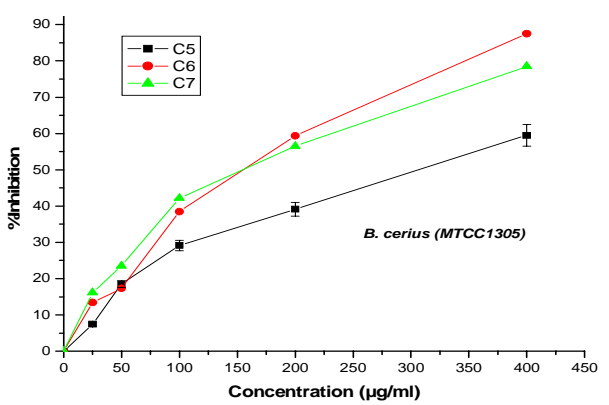

Fig.4. Growth Inhibition of B. cereus at Different Concentration of Synthesized Mannofuranoside derivatives (C5, C6 \& C7) was Recorded After 19 hours

\section{EXPERIMENTAL}

Synthesis of 2,3,5,6-di-O-isopropylidene- $\alpha-D$ mannofuranose $(\mathbf{C} 1)^{36}$

Yield $87 \%$, Rf $0.74, \mathrm{mp}=124-126 \mathrm{pC}$; Proton NMR (300 MHz, $\left.\mathrm{CDCl}_{3}\right): \delta 4.83-4.79(\mathrm{~m}, 1 \mathrm{H})$; 


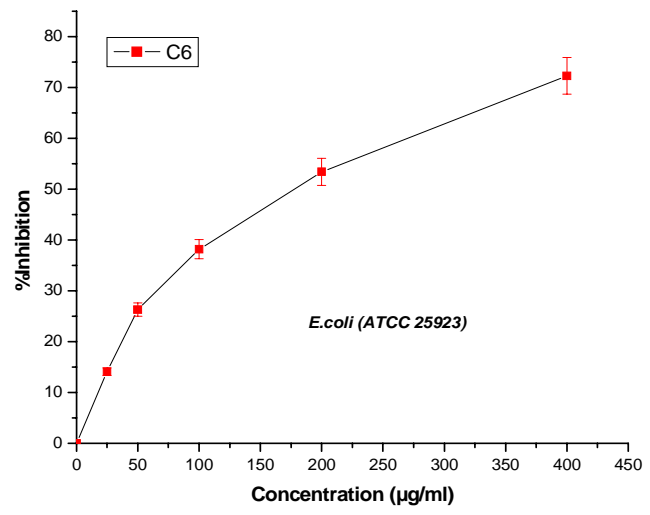

Fig.5. Growth Inhibition of e.coli at different concentration of synthesized mannofuranoside derivative (C6) was recorded After 16 hours

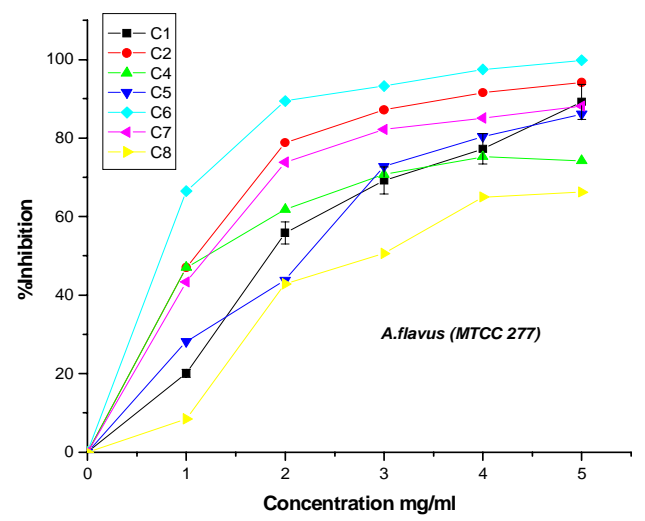

Fig. 6. Growth inhibition of $\boldsymbol{A}$. flavus strain at different concentration of synthesized mannofuranoside derivatives (C1, C2, C4-C8) was recorded after 48 hours

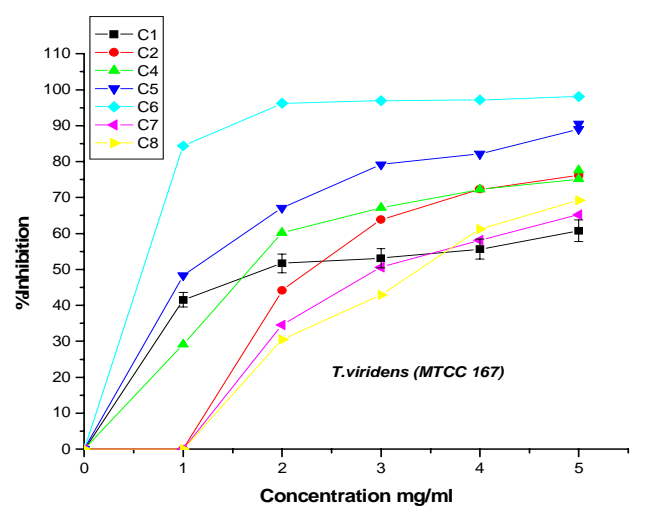

Fig.7. Growth inhibition of $T$. viridens strain at different concentration of synthesized mannofuranoside derivatives (C1, C2, C4-C8) were recorded after 52 hours

$\delta$ 4.46-4.42 (m, 1H); $\delta 4.61-4.63(\mathrm{~d}, \mathrm{~J}=5.6 \mathrm{~Hz}, 1 \mathrm{H}$,); 4.18-4.21 (m, $1 \mathrm{H}) ; \delta 4.05-4.17$ (dd, J = $2.1 \mathrm{~Hz}, 1.2$ $\mathrm{Hz}, 2 \mathrm{H}) ; \delta 3.1(\mathrm{~s}, 1 \mathrm{H}) ; \delta 1.47, \delta 1.46, \delta 1.38 \& \delta 1.33$ (s, 3H); ${ }^{13} \mathrm{C}$ NMR $\left(75 \mathrm{MHz}, \mathrm{CDCl}_{3}\right) \delta: 113.4,112.7$, 109.4, 109.2, 101.2, 101.0, 97.2, 85.6, 80.1, 79.7, 79.4, 79.1, 78.6, 76.8, 76.2, 73.4, 73.0, 70.1, 67.1, 27.0, 26.8, 25.9, 25.8; $\mathrm{MS}(\mathrm{m} / \mathrm{z})=261(\mathrm{M}+1)$; IR $(\mathrm{KBr}):\left(\mathrm{v} \mathrm{cm}^{-1}\right): 3431,2982,2875$; Anal. Calcd for $\mathrm{C}_{12} \mathrm{H}_{20} \mathrm{O}_{6}$ : Calculated $\mathrm{C}, 55.37 ; \mathrm{H}, 7.74$ Found $\mathrm{C}$, $55.29 ; \mathrm{H}, 7.71$

Synthesis of 2, 3, 5, 6-di-O-isopropylidene-1-0trichloroacetamidyl- $\alpha$-D-mannofuranose $(\mathrm{C} 2)^{36}$

Yield 66\%, Rf 0.92, $\mathrm{mp}=103-105 \mathrm{pC}$; Proton NMR (300 MHz, $\left.\mathrm{CDCl}_{3}\right)$ : $\delta 8.59(\mathrm{~s}, 1 \mathrm{H},-\mathrm{NH})$; $\delta 6.26(\mathrm{~s}, 1 \mathrm{H}) ; \delta 4.94(\mathrm{~m}, 2 \mathrm{H}) ; \delta 4.42(\mathrm{~m}, 1 \mathrm{H}) ; 4.04(\mathrm{~m}$, $3 \mathrm{H}$ ); $\delta$ 4.05-4.17 (dd, J = 2.1 Hz, $1.2 \mathrm{~Hz}, 2 \mathrm{H}$ ); $\delta 1.59$, $\delta 1.50, \delta 1.45 \& \delta 1.33(\mathrm{~s}, 3 \mathrm{H}) ;{ }^{13} \mathrm{C}$ NMR $\left(\mathrm{CDCl}_{3}, 75\right.$ $\mathrm{MHz}) \delta: 160.8,113.6,112.7,109.6,109.2,104.9$, $101.4,91.1,85.6,84.9,83.0,80.5,79.8,79.4,79.1$, 76.8, 73.4, 72.8, 67.2, 66.8, 27.1, 26.1, 25.3, 24.9; $\mathrm{MS}(\mathrm{m} / \mathrm{z})=404(\mathrm{M}+1)$; IR $(\mathrm{KBr}):\left(\mathrm{v} \mathrm{cm}^{-1}\right): 3794,3334$, 2988Anal. Calcd for $\mathrm{C}_{14} \mathrm{H}_{20} \mathrm{O}_{6} \mathrm{NCl}_{3}$ : Calculated $\mathrm{C}$, 40.68; H, 4.98; N, 3.46; Found C, 41.08, H, 4.81, N 3.38.

\section{Synthesis of 7-(2-hydroxyethoxy)-4-methyl coumarin (C3)}

A mixture 7-hydroxyl-4-methyl coumarin (5.0 gm, $22.72 \mathrm{mmol}$ ), 2-bromoethanol (5.0 gm, $40.65 \mathrm{mmol}$ ) and potassium carbonate $(3.0 \mathrm{gm}$, $21.89 \mathrm{mmol})$ are taken in flat bottom flask $(25 \mathrm{ml})$ and refluxed for $24 \mathrm{~h}$. in ethanol $(100 \mathrm{ml})$. After cooling treated with ether and water (1:1) then separated. The aqueous layer further washed with ether $(2 \times 20 \mathrm{ml})$, both organic layers combined; add sodium sulphate to dry and solvent evaporate under reduced pressure obtained residue was directly allow to column chromatography using hexane/ethyl acetate (4/6) to give the desired compound C3 with interesting yield for crystallization ether was added and 7-(2hydroxyethoxy)-4-methyl coumarin obtained in the form of white crystalline solid.

Yield 58\%, mp = 128-130 pC; Proton NMR $\left(300 \mathrm{MHz}, \mathrm{CDCl}_{3}\right): \delta 7.67(\mathrm{~d}, \mathrm{~J}=1.5 \mathrm{~Hz}, 1 \mathrm{H}) ; \delta 6.83(\mathrm{~d}$, $\mathrm{J}=2.3 \mathrm{~Hz}, 1 \mathrm{H}) ; \delta 6.93 \& \delta 6.91$ (dd, $1.6 \& 1.2 \mathrm{~Hz}$, $1 \mathrm{H}) ; \delta 6.57(\mathrm{~s}, 1 \mathrm{H}) ; \delta 1.97(\mathrm{~s}, 3 \mathrm{H}) ; \delta 2.6(\mathrm{~s}, 1 \mathrm{H},) ; \delta 3.69$ $(\mathrm{t}, 2 \mathrm{H}) ; \delta 4.33(\mathrm{t}, 2 \mathrm{H}) ;{ }^{13} \mathrm{C}$ NMR $\left(75 \mathrm{MHz}, \mathrm{CDCl}_{3}\right) \delta$ : $161.9,161.6,155.3,152.8,125.8,114.1,113.3$, 112.7, 112.3, 111.6, 103.5, 101.8, 69.9, 61.3, 19.3; $\mathrm{MS}(\mathrm{m} / \mathrm{z})=221(\mathrm{M}+1)$; IR $(\mathrm{KBr})\left(\mathrm{v} \mathrm{cm}^{-1}\right): 3452 ; 3021$, 
2982, 1720 Anal. Calcd for $\mathrm{C}_{11} \mathrm{H}_{8} \mathrm{O}_{4}$ : Calculated $\mathrm{C}$, 64.07; H, 4.89; Found C, 64.01, H, 4.74.

Synthesis of 7-0-ethoxy- $\alpha-(2,3,5,6-d i-0-$ isopropylidene-mannofuranosyl)-4-methylcoumarin (C4)

To synthesized $\mathrm{C} 4$, the mixture of $\mathrm{C} 2(1.21$ $\mathrm{gm}, 3.0 \mathrm{mmol})$ and $\mathrm{C} 3(0.61 \mathrm{gm}, 3.0 \mathrm{mmol})$ was stirred in dry dichloromethane $\mathrm{CH}_{2} \mathrm{Cl}_{2}(15 \mathrm{ml})$ in the presence of trimethylsilyl trifluoro-methanesulfonate TMSOTf $(60 \mu \mathrm{l}, 0.30 \mathrm{mmol})$ and molecular sieve $\left(1.0 \mathrm{gm}, 4 \mathrm{~A}^{\circ}\right)$ for $1.5 \mathrm{~h}$. at room temperature and then solvent evaporated under reduced pressure obtained residue was directly allow to column chromatography using hexane/ethyl acetate (9/1) to give the desired compound $\mathrm{C} 4$ as white crystalline solid with interesting yield.

Yield $49 \%$, Rf $0.62, \mathrm{mp}=116-118 \mathrm{pC}$; Proton NMR ( $\left.300 \mathrm{MHz} \mathrm{CDCl}_{3}\right): \delta 7.67(\mathrm{~d}, \mathrm{~J}=1.5 \mathrm{~Hz}$, $1 \mathrm{H}) ; \delta 6.83(\mathrm{~d}, \mathrm{~J}=2.3 \mathrm{~Hz}, 1 \mathrm{H}) ; \delta 6.91-6.89$ (dd, 1.6 \& $1.5 \mathrm{~Hz}, 1 \mathrm{H}) ; \delta 6.57(\mathrm{~s}, 1 \mathrm{H}) ; \delta 5.62(\mathrm{~s}, 1 \mathrm{H}), \delta 4.87(\mathrm{~m}$, $1 \mathrm{H}) ; \delta 4.91(\mathrm{~m}, 1 \mathrm{H}) \delta 4.42-4.39(\mathrm{~m}, 1 \mathrm{H}) ; \delta 4.62-4.60$ $(\mathrm{d}, \mathrm{J}=7.5 \mathrm{~Hz}, 1 \mathrm{H}) ; \delta 4.16-4.18$ (dd, J = $2.0 \mathrm{~Hz}, 1.5$ $\mathrm{Hz}, 2 \mathrm{H}) ; \delta 1.97(\mathrm{~s}, 3 \mathrm{H}) ; \delta 3.69(\mathrm{t}, 2 \mathrm{H}) ; \delta 4.33(\mathrm{t}, 2 \mathrm{H}) ; \delta$ $1.49, \delta 1.43, \delta 1.35 \& \delta 1.32(\mathrm{~s}, 3 \mathrm{H}) ;{ }^{13} \mathrm{C}$ NMR $(75$ $\left.\mathrm{MHz}, \mathrm{CDCl}_{3}\right) \delta: 164.1,161.9,160.2,126.1,125.9$, 113.3, 112.8, 112.2, 111.5, 103.5, 101.7, 91.9, 69.8, 61.3, 29.8, 27.0, 26.0, 26.3, 24.7, 18.9; $\mathrm{MS}(\mathrm{m} / \mathrm{z})$ $=463(\mathrm{M}+1)$; IR $(\mathrm{KBr})\left(\mathrm{v} \mathrm{cm}^{-1}\right): 3282,3021,2974$, 1720 ;Anal. Calcd for $\mathrm{C}_{24} \mathrm{H}_{30} \mathrm{O}_{9}$ : Calculated C, 62.33; $\mathrm{H}, 6.54$; Found $\mathrm{C}, 64.46, \mathrm{H}, 6.62$.

Synthesis of 3-0-methoxy-4'-0- $\alpha-(2,3,5,6-\mathrm{di}-0-$ isopropylidene- mannofuranosyl) benzoic acid (C5)

To synthesized C5, the mixture of C2 (1.21 $\mathrm{gm}, 3.0 \mathrm{mmol}$ ) and vanillin $(0.50 \mathrm{gm}, 3.0 \mathrm{mmol})$ was stirred in dry dichloromethane $\mathrm{CH}_{2} \mathrm{Cl}_{2}(15 \mathrm{ml})$ in the presence of trimethylsilyl trifluoro-methanesulfonate TMSOTf $(60 \mu \mathrm{l}, 0.30 \mathrm{mmol}$ ) and molecular sieve $\left(1.0 \mathrm{gm}, 4 \mathrm{~A}^{\circ}\right)$ for $2.5 \mathrm{~h}$. at room temperature and then solvent evaporated under reduced pressure obtained residue was directly allow to column chromatography using hexane/ethyl acetate (9/1) to give the desired compound $\mathrm{C} 5$ as light yellow crystalline solid with sufficient yield.

Yield 45\%, Rf 0.42, $\mathrm{mp}=97-99 \mathrm{pC}$; Proton NMR (300 MHz CDCl$)$ ): $\delta 11.74(\mathrm{~s}, 1 \mathrm{H}) ; \delta 7.81(\mathrm{~d}, \mathrm{~J}$ $=1.5 \mathrm{~Hz}, 1 \mathrm{H}) ; \delta 7.41-7.38(\mathrm{dd}, \mathrm{J}=1.5 \mathrm{~Hz} \& 1.2 \mathrm{~Hz})$; $\delta 7.16(\mathrm{~d}, \mathrm{~J}=1.5 \mathrm{~Hz}, 1 \mathrm{H}) ; \delta 5.69(\mathrm{~s}, 1 \mathrm{H}), \delta 4.93(\mathrm{~m}$, $1 \mathrm{H}) ; \delta 4.89(\mathrm{~m}, 1 \mathrm{H}) ; \delta 4.41-4.38(\mathrm{~m}, 1 \mathrm{H}) ; \delta 4.63-4.61$ $(\mathrm{d}, \mathrm{J}=7.0 \mathrm{~Hz}, 1 \mathrm{H}) ; \delta 4.13-4.19(\mathrm{dd}, \mathrm{J}=2.2 \mathrm{~Hz}, 1.2$ $\mathrm{Hz}, 2 \mathrm{H}) ; \delta 3.92(\mathrm{~s}, 3 \mathrm{H}) ; \delta 1.56, \delta 1.53, \delta 1.36 \& \delta 1.32$ $(\mathrm{s}, 3 \mathrm{H}) ;{ }^{13} \mathrm{C}$ NMR $\left(75 \mathrm{MHz}, \mathrm{CDCl}_{3}\right) \delta: 169.5,151.1$, 145.8, 144.7, 126.7, 124.3, 124.2, 123.8, 116.4, $115.1,111.4,103.6,101.2,85.5,71.2,56.2,26.2$, 25.2, 25.0, 23.8; $\mathrm{MS}(\mathrm{m} / \mathrm{z})=411(\mathrm{M}+1)$; IR $(\mathrm{KBr})$ $\left(v \mathrm{~cm}^{-1}\right): 3298,2925,2870,1690$;Anal. Calcd for $\mathrm{C}_{20} \mathrm{H}_{26} \mathrm{O}_{9}$ : Calculated C, 58.53; $\mathrm{H}, 6.39$; Found C, $58.62, \mathrm{H}, 6.35$.

Synthesis of 8-0- $\alpha-(2,3,5,6-d i-0-i s o p r o p y l i d e n e-$ mannofuranosyl)-quinoline (C6)

To synthesized C6, the mixture of $\mathrm{C} 2(1.21$ $\mathrm{gm}, 3.0 \mathrm{mmol})$ and 8 -Hydroxy quinoline $(0.87 \mathrm{gm}$, $6.0 \mathrm{mmol}$ ) was stirred in dry dichloromethane $\mathrm{CH}_{2} \mathrm{Cl}_{2}(15 \mathrm{ml})$ in the presence of trimethylsilyl trifluoromethanesulfonate TMSOTf $(60 \mu \mathrm{l}, 0.30$ $\mathrm{mmol})$ and molecular sieve $\left(1.0 \mathrm{gm}, 4 \mathrm{~A}^{\circ}\right)$ for $1.5 \mathrm{~h}$. at room temperature and then solvent evaporated under reduced pressure obtained residue was directly allow to column chromatography using hexane/ethyl acetate (9/1) to give the desired compound $\mathrm{C} 6$ as white crystalline solid with sufficient yield.

Yield 44\%, Rf 0.65, $\mathrm{mp}=110-113 \mathrm{pC}$; Proton NMR ( $\left.300 \mathrm{MHz} \mathrm{CDCl}_{3}\right): \delta 8.73(\mathrm{~d}, \mathrm{~J}=7.5 \mathrm{~Hz}$, $1 \mathrm{H}) ; \delta 7.52(\mathrm{t}, 1.5 \mathrm{~Hz}, 1 \mathrm{H}) ; \delta 7.40(\mathrm{~d}, \mathrm{~J}=1.2 \mathrm{~Hz}, 1 \mathrm{H})$; $\delta 7.16(\mathrm{~d}, \mathrm{~J}=1.5 \mathrm{~Hz}, 1 \mathrm{H}) ; \delta 7.41(\mathrm{t}, 1.2 \mathrm{~Hz}, 1 \mathrm{H}) ; \delta 7.24$ $(\mathrm{d}, \mathrm{J}=1.5 \mathrm{~Hz}, 1 \mathrm{H}) ; \delta 5.71(\mathrm{~s}, 1 \mathrm{H}), \delta 4.98(\mathrm{~m}, 1 \mathrm{H}) ; \delta$ $4.91(\mathrm{~m}, 1 \mathrm{H}) \delta 4.42-4.39(\mathrm{~m}, 1 \mathrm{H}) ; \delta 4.62-4.60(\mathrm{~d}, \mathrm{~J}=$ $7.5 \mathrm{~Hz}, 1 \mathrm{H}) ; \delta 4.16-4.18(\mathrm{dd}, \mathrm{J}=2.0 \mathrm{~Hz} \& 1.5 \mathrm{~Hz}$, $2 \mathrm{H}) ; \delta 1.36, \delta 1.34, \delta 1.27 \& \delta 1.25(\mathrm{~s}, 3 \mathrm{H}) ;{ }^{13} \mathrm{C}$ NMR $\left(75 \mathrm{MHz}, \mathrm{CDCl}_{3}\right) \delta: 163.9,152.3,148.0,138.4$, $136.3,128.7,127.9,122.0,118.1,113.0,110.2$, 109.5, 109.2, 101.7, 101.5, 92.0, 85.6, 85.2, 81.1, $80.5,79.8,73.4,73.1,67.1,66.7,29.8,27.0,26.0$, 25.3, 24.7; $\mathrm{MS}(\mathrm{m} / \mathrm{z})=388(\mathrm{M}+1) ; \mathrm{IR}(\mathrm{KBr})\left(\mathrm{v} \mathrm{cm}^{-1}\right)$ : 3382, 2988, 2881;Anal. Calcd for $\mathrm{C}_{21} \mathrm{H}_{25} \mathrm{O}_{6} \mathrm{~N}$ : Calculated C, 65.10; H, 6.50, N, 3.62; Found C, $65.15, \mathrm{H}, 6.59, \mathrm{~N}, 3.71$.

Synthesis of $1-0-\alpha-(2,3,5,6-d i-0-i s o p r o p y l i d e n e-$ mannofuranosyl)-1H-benzo-1,2,3-triazole (C7)

To synthesized $\mathrm{C} 7$, the mixture of $\mathrm{C} 2(1.21$ $\mathrm{gm}, 3.0 \mathrm{mmol})$ and 1-Hydroxy benzotriazole $(0.86$ $\mathrm{gm}, 6.4 \mathrm{mmol}$ ) was stirred in dry dichloromethane $\mathrm{CH}_{2} \mathrm{Cl}_{2}(15 \mathrm{ml})$ in the presence of trimethylsilyl trifluoromethanesulfonate TMSOTf $(60 \mu \mathrm{l}, 0.30$ 
$\mathrm{mmol})$ and molecular sieve $\left(1.0 \mathrm{gm}, 4 \mathrm{~A}^{\circ}\right)$ for $1.5 \mathrm{~h}$ at room temperature and then solvent evaporated under reduced pressure obtained residue was directly allow to column chromatography using hexane/ethyl acetate (9/1) to give the desired compound $\mathrm{C} 7$ as colourless oil with sufficient yield.

Yield 48\%, Rf 0.65, $\mathrm{mp}=118-120 \mathrm{pC}$; Proton NMR(300 MHz $\left.\mathrm{CDCl}_{3}\right): \delta 7.69(\mathrm{~m}, 2 \mathrm{H}) ; \delta 7.38-$ $7.56(\mathrm{~m}, 2 \mathrm{H}, \mathrm{Ar}-\mathrm{H}) ; \delta 5.81(\mathrm{~s}, 1 \mathrm{H}), \delta 4.94(\mathrm{~m}, 1 \mathrm{H}) ; \delta$ $4.92(\mathrm{~m}, 1 \mathrm{H}) \delta 4.42-4.58(\mathrm{~m}, 1 \mathrm{H}) ; \delta 4.81-4.83(\mathrm{~d}, \mathrm{~J}=$ $7.0 \mathrm{~Hz}, 1 \mathrm{H}$ ); $\delta$ 4.04-4.12 (dd, J = 2.0 Hz \& $1.5 \mathrm{~Hz}$, $2 \mathrm{H}) ; \delta 1.47, \delta 1.40, \delta 1.35 \& \delta 1.31(\mathrm{~s}, 3 \mathrm{H}) ;{ }^{13} \mathrm{C}$ NMR $\left(75 \mathrm{MHz} \mathrm{CDCl}_{3}\right) \delta: 144.8,144.7,135.1,130.8$, 129.8, 129.6, 128.8, 128.1, 114.3, 114.2, 113.8, 113.2, 96.8, 96.7, 79.5, 63.2, 27.0, 26.0, 25.3, 24.8, 24.72; $\mathrm{MS}(\mathrm{m} / \mathrm{z})=378(\mathrm{M}+1)$; IR $(\mathrm{KBr})\left(\mathrm{v} \mathrm{cm}^{-1}\right)$ : 3039 2917; Anal. Calcd for $\mathrm{C}_{18} \mathrm{H}_{23} \mathrm{O}_{6} \mathrm{~N}_{3}$ : Calculated $\mathrm{C}$ 57.29; H, 6.14, N, 11.13; Found C, 57.23, H, 6.04 N, 11.28.

Synthesis of 2-0-methyl- $\alpha-(2,3,5,6-d i-0-$ isopropylidene-mannofuranosyl) furan (C8)

To synthesized C8, the mixture of C2 (1.21 gm, $3.0 \mathrm{mmol}$ ) and 2-(Hydroxymethyl) furan (0.61 $\mathrm{ml}, 6.0 \mathrm{mmol}$ ) was stirred in dry dichloromethane $\mathrm{CH}_{2} \mathrm{Cl}_{2}(15 \mathrm{ml})$ in the presence of trimethylsilyl trifluoromethanesulfonate TMSOTf $(60 \mu \mathrm{l}, 0.30$ $\mathrm{mmol}$ ) and molecular sieve $\left(1.0 \mathrm{gm}, 4 \mathrm{~A}^{\circ}\right)$ for $2.5 \mathrm{~h}$. at room temperature and then solvent evaporated under reduced pressure obtained residue was directly allow to column chromatography using hexane/ethyl acetate (9/1) to give the desired compound $\mathrm{C} 8$ as crystalline solid.

Yield 38\%, Rf 0.59, mp = 112-114 pC; Proton $\operatorname{NMR}(300 \mathrm{MHz} \mathrm{CDCl})$ ): $\delta 3.92(\mathrm{~s}, 1 \mathrm{H}) ; \delta 6.24$ (d, d = 7.5 $\mathrm{Hz}, 1 \mathrm{H}) ; \delta 6.27$ (t, $1 \mathrm{H}) ; \delta 6.98(\mathrm{~d}, 1.2 \mathrm{~Hz}, 1 \mathrm{H}) ; \delta 5.53$ (s, $1 \mathrm{H}), \delta 4.83(\mathrm{~m}, 1 \mathrm{H}) ; \delta 4.979(\mathrm{~m}, 1 \mathrm{H}) \delta 4.38-4.47(\mathrm{~m}, 1 \mathrm{H})$; $\delta 4.74-4.79(\mathrm{~d}, \mathrm{~J}=7.0 \mathrm{~Hz}, 1 \mathrm{H}) ; \delta 4.03-4.11(\mathrm{dd}, \mathrm{J}=2.0 \mathrm{~Hz}$ $\& 1.5 \mathrm{~Hz}, 2 \mathrm{H}) ; \delta 1.42, \delta 1.35, \delta 1.31 \& \delta 1.29 ;{ }^{13} \mathrm{C} \operatorname{NMR}(75$ $\left.\mathrm{MHz}, \mathrm{CDCl}_{3}\right) \delta: 152.8,143.8,113.7,112.7,109.2,107.9$, 101.2, 85.6, 80.1, 79.7, 73.0, 64.1, 26.0, 25.8, 24.9, 24.8; $\mathrm{MS}(\mathrm{m} / \mathrm{z})=341(\mathrm{M}+1)$; IR $\left.(\mathrm{KBr})(\mathrm{v} \mathrm{cm})^{-1}\right): 3282,2974$; Anal. Calcd for $\mathrm{C}_{17} \mathrm{H}_{24} \mathrm{O}_{7}$ : Calculated C, 59.99; $\mathrm{H}, 7.11$, $\mathrm{N}$; Found C, 59.90, H, 7.16.

\section{Structure activity relationship (SAR):}

The synthesized compounds selected for the antimicrobial activity had the same parenta skeleton. The most important things for the activity were due to substituent's which attached to parent skeleton. The mannofuranoside derivative, 8-O- $\alpha$ (2,3,5,6-di-O-isopropylidene-mannofuranosyl)quinoline (C6) have $\mathrm{IC}_{50} 84.28 \mu \mathrm{g} / \mathrm{ml}$ against $S$. aureus due to the presence of quinoline as heterocyclic substituent. Secondary nitrogen of the quinoline having a nucleophilic centre has been found essential for activity. The mannofuranoside derivative, Synthesis of 3-O-methoxy-4'-O- $\alpha$ (2,3,5,6-di-O-isopropylidene- mannofuranosyl) benzoic acid (C5) have maximum $\mathrm{IC}_{50} 309.43 \mu \mathrm{g} /$ $\mathrm{ml}$ against $B$. cerius because they have ethoxy group as substituent. ethoxy group destabilize the ring and reduced activity. The mannofuranoside derivative, 8-O- $\alpha$-(2,3,5,6-di-O-isopropylidenemannofuranosyl)-quinoline (C6) have $\mathrm{IC}_{50} 0.59 \mathrm{mg} /$ $\mathrm{ml}$ against $T$. viridens due to the presence of quinoline as heterocyclic substituent. Secondary nitrogen of the quinoline having a nucleophilic centre has been found essential for activity. The mannofuranoside derivative, 2-O-methyl- $\alpha$ (2,3,5,6-di-O-isopropylidene-mannofuranosyl) furan (C8) have $I_{50} 3.82 \mathrm{mg} / \mathrm{ml}$ against $T$. viridens having methyl furanyl as heterocyclic substituent. Methyl group destabilize the ring and reduced activity.

Eight mannofuranoside derivatives were synthesized and $\mathrm{IC}_{50}$ was determined for all derivatives. From the $\mathrm{IC}_{50}$ value depicted in table-1 it can be concluded that mannofuranoside with quinoline as heterocyclic substituent (C6) is more potent than coumarin analogue (C4), Phenolic (C5), triazole (C7)and methyl furanyl analogue (C8).

In this study, synthesized mannofuranoside derivatives, were found to be as strong antifungal agents. In addition, these compounds inhibited few pathologically important gram positive and gram negative bacteria also. As they gave significant antifungal potential, these compounds could be further improved to form broad spectrum antifungal agents. In addition, none of these mannofuranoside derivatives gave violation of Lipinski's Rule of Five. Further studies would be needed to decipher the exact mechanism of anti-microbial/anti-fungal action of these derivatives. However, we can safely state that the present study has provided some potent antimicrobial drug candidates in the form of mannofuranoside derivatives. 


\section{ACKNOWLEDGEMENT}

The authors are grateful to thank the R\&D wing of Integral University, Lucknow, for support and provide communication number (IU/R\&D/2017-
MCN00021) for the manuscript and authors are also thankful to Mr. Wajid Ali, IIT, Guwahati, Ms. Deepti Saxena, Tahseen Akhtar, Javed, CDRI, Lucknow, India for their help in spectroscopic data analysis.

\section{REFERENCES}

1. Wilson, C.L. Microbial Food Contamination, CRC Press, Taylor \& Francis Group, LLC: Boca Raton, FL, USA. 2007.

2. Shen, Y.; Sun, Y.; Sang, Z.; Sun, C.; Dai, Y.; Deng, Y. Molecules. 2012, 17, 8661-8673.

3. Nelson, D.L.; Cox, M.M. Lehninger Principle of Biochemistry, Macmillan, USA. 2004, 238- 254.

4. Ritter, T.K.; Wong, C.H. Angew. Chem. Int. Ed. Engl. 2001, 40, 3508-3533.

5. Nogueira, C.M.; Parmanhan, B.R.; Farias, P.P.; Correa, A.G. Rev. Virtual Quim. 2009, 1,149-159.

6. Wong, C. Carbohydrate-based Drug Discovery, Wiley-VCH Verlag GmbH \& Co. KGaA, Weinheim, Germany. 2003

7. Aboelmagd, A.; Ibrahim, A.I.A.; Ezzeldin, M.S.S.; Razik, M.A. ARKIVOC. 2011, 9, 337-353.

8. Mamdouh, A.S.;Samy, B.S.; Kandeel, H.S.Der Pharma Chemica. 2012, 4, 1064-1073.

9. Mohammed, M.M.; Bhuiyan, M.M.H.; Dulal, C.D.; Manchur, M.A. Int. J. Biosci. 2013, 3, 279-287.

10. Katritzky, A.R. In Comprehensive Heterocyclic Chemistry, Elsevier Science and Technology ISBN: 0080420729. 1996, 11628.

11. Govori, S.; Rapic, V.; Leci, O.; Cacic, M.; Tabakovic, I. J. Heterocycl. Chem. 1996, 33, 351-354.

12. Govori, S.; Spahiu, S.; Kalaj, V.; Leci, O.; Haziri, A.; Ibrahimi, H. Am. Jour. of Bioch. and Biotechnol. 2010, 6, 275-278

13. Feng, X.U.; Ding, Q.; Yang, K.; Jing, W.G. Chinese Chem. Lett. 2006, 17, 187-190.

14. Gramik, V.G.; Zhidkava, A.M.; Kiselev, S.S.; Ghohkov, R.G.; Polezhaeva, A.J; Moshkovshi, M.D.J Pharm Chem. 1978, 12, 881.

15. Senthil, S.; Gopi, R. Der Pharma Chemica. 2015, 7, 15-23.

16. Solon, S.; Brandao, C.A.Ce.L.F.G. Quim. Nova. 2012, 35, 1169-1172.
17. Alves, M.J.;Ferreira, I.C.F.R.; Froufe, H.J.C.; Abreu, R.M.V.; Martins, A.; Pintado, M. Journal of Applied Microbiology. 2013, 115, 346-357.

18. Gupta, R.; Paul, S.; Gupta, A.K.; Kachroo, P.L.; Bani, S. Indian J. Chem. 1997, 36, 707-710.

19. Kabir, A.K.M.S.; Matin, M.M.; Bhuiyan, M.M.R.; Rahim, M.A. Chittagong Univ. J. Sci. 2001, 25, 85-94.

20. Hassan,F.; Kamal, A.; Ahmad, N.; Nasibullah, M.; Khan, M.S.; Khan, A.R. Inter. J. of Chem. 2013, 34,1395-1402.

21. Nogueira,C.M.; Parmanhan, B.R.; Farias, P.P.; Corrêa, A.G. Rev.Virtual Quim. 2009, 1, 149-159.

22. Cao, H.; Hwang, J.; Chen, Xi. Carbohydratecontaining natural products in medicinal chemistry. InL Edn. 2011, 411-431.

23. Cipolla, L.; La Ferla, B.; Airoldi, C.; Zona, C.; Orsato, A.; Shaikh, N.; Russo, L.; Nicotra, F. Fut. Med. Chem. 2010, 2, 587-599.

24. Cipolla, L.; Gregori, M.; So, P.W. Curr. Med. Chem. 2011, 8, 1002-1018.

25. Cipolla, L.;Peri, F. Mini-Rev. Med. Chem. 2011, 11, 39-54.

26. Lonngren, J. Pure Appl. Chem. 1989, 61, 1313-1314.

27. Horne, G.; Wilson, F.X.;Prog. Med. Chem. 2011, 50, 135-176.

28. Etayo, P.; Badorrey, R.; Villegas, M.D.; Galvez, G.A.; Víu, P.L. Synlett. 2010, 12, 1775-1778.

29. Andry, C.;Wylde, R.; Laffite, C.;Privat, G.;Winternitz, F. Phytochem. 1982, 21, 1123-1127.

30. Ishi, H.; Nakamura, M.; Seo, S.; Tori, K.; Tozyo, T. Chem. Pharm. Bull. 1980, 28, 2367-2373.

31. Schmidt, R.R.; Michel, J. Angew. Chem. 1980, 92, 763-764.

32. Aype, N.; Duygu, A.T.I.; Hakký, A.; Tansel, O.Y.; Ýsmet, D.G; Ýsmail, K. FABAD J. Pharm. Sci. 2008, 33, 77-86.

33. Dulger, G.; Aki, C. Trop. J.I of Pharmace. Res. 2009, 8, 371-375.

34. Annette, W.F.; Rinaldi, M.G.; Sutton, D.A. Infect 
Dis. Clin N Am. 2006, 20, 699-709.

35. Kratzer, C.; Tobudic, S.; Schmoll, M.; Graninger, W.; Georgopoulos, A. Journal of Antimicrobial Chemotherapy. 2006, 58, 1058-1061.

36. Filice, M.; Guisan, J.M.; Palomo, J.M. Curr. Org. Chem. 2010, 14, 516-532.

37. Obi, M.; Morino, S.; Ichimura, K. Chem. Mat. 1999, 11, 656-664.

38. Bauer, A.W.; Kirby, W.M.; Sherris, J.C.; Turch, M. Am. J. Clin. Pathol. 1966, 4, 5493-496.

39. Amsterdam, D. In Lorian V. ed. Antibiotics in Laboratory Medicine, (Lippincott Williams \& Wilkins Philadelphia P A). 2005, 72-78.

40. Pryor, W.S.; Gibson, M.D.; Bergstrom, C.G.; Walker, P.L.BioTechniques. 2007, 42, 168-172.
41. Hadacek, F.; Greger, H.; Phytochem. Anal. 2000, 11, 137-147.

42. Grover, R.K.; Moore, J.D. Phytopathol. 1962, 52, 876-880.

43. Miah, M.A.T.; Ahmed, H.U.; Sharma, N.R.; Ali, A.; Miah, S.A.; Bangladesh. J. Bot. 1990, 19, 5-10.

44. Lipinski, C.A.; Lombardo, F.; Dominy, B.W.; Feeney, P.J. Adv Drug Deliv Rev. 2001, 46, 3-26.

45. Azam, F, Mohamed, N.; Alhussen, F. Network: Computation in neural systems. 2015, 26, 97-115.

46. Zhao, Y.H.; Abraham, M.H.; Le, J.; Hersey, A.; Luscombe, C.N.; Beck, G.; Sherborne, B.; Cooper, I. Pharm. Res. 2002, 19, 1446-1457. 